\title{
Spring growth of caddisflies (Limnephilidae : Trichoptera) in response to marine-derived nutrients and food type in a Southeast Alaskan stream
}

\author{
J.L. Lessard ${ }^{1 *}$, R.W. Merritt ${ }^{2}$, K.W. Cummins ${ }^{3}$ \\ ${ }^{1}$ Department of Entomology, 243 Natural Science Bldg., Michigan State University, East Lansing, MI 48824, USA. ; \\ 2 Departments of Entomology and Fisheries and Wildlife, 243 Natural Science Bldg., Michigan State University, East Lansing, MI 48824, USA.; \\ ${ }^{3}$ Institute for Forestry and Watershed Management, Humboldt State University, Arcata, CA 95521, USA.
}

\begin{abstract}
The short-term stimulation of production, due to marine-derived nutrients (MDN) from spawning salmon, is well documented for certain trophic levels in stream communities (e.g., algae and insect biomass). The effect of these nutrients on the stream ecosystem as a whole, however, remains unclear especially later in the year. Trichopterans have been shown to feed on salmon and other fish carcasses and there is evidence for greater growth rates in the presence of salmon tissue. To address the question of long-term MDN subsidy on trichopterans, we investigated the growth of three limnephilid caddisflies in the spring in the Harris River on Prince of Wales Island, Southeast Alaska. The Harris River has a natural waterfall barrier to salmon and receives large runs of pink (O. gorbuscha) and chum $(O$. keta) salmon each fall. We selected two shredding caddisflies (Onocosmoecus unicolor) and (Psychoglypha spp.) and one facultative scraper, (Dicosmoecus atripes) for our study. We had two objectives : 1) compare the spring growth of larval caddisflies in a stream section that receives a large autumn run of salmon with their growth in a stream section that is blocked from receiving salmon (due to an impassable waterfall), and 2) compare the growth of shredders with that of a facultative scraper when provided either leaves or biofilm on rocks as food.

Insects were placed in growth boxes in May 2001 with either conditioned alder leaves or stream rocks as food sources. The boxes were placed along with temperature loggers in both the salmon (below the waterfall) and non-salmon (above the waterfall) reaches. The boxes were removed 40 days later. In-stream samples were taken of each caddisfly initially and at the end of the experiment to establish in-stream growth versus growth in the boxes. All larvae were coaxed from their cases, measured for total wet length, dried and weighed. Only D. atripes and Psychoglypha spp. were growing during our experiment and both showed very high relative growth rates in the Harris River. Psychoglypha spp. and O. unicolor were both significantly larger in the leaf boxes and $D$. atripes was significantly larger in the rock boxes. Both $D$. atripes and Psychoglypha spp. had significantly greater relative growth rates between food types (on biofilm on rocks and leaves respectively). These results support the notion that $D$. atripes are most likely facultative scrapers at least in their first year of growth. None of these caddisflies showed differences in their final mean weights or relative growth rates between stream sections, suggesting no effect of MDN on their spring growth in the Harris River. Further research on caddisfly communities in the fall and winter will help clarify if MDN has an influence on the abundance and life history of these species closer to the salmon run. This study questions the long-term influence of MDN on stream communities, particularly those populations that do most of their production in the spring, months after salmon carcasses are no longer visible.
\end{abstract}

Keywords : Trichoptera, growth, marine-derived nutrients, Alaska, streams.

\footnotetext{
* corresponding author : E-mail : lessard4@pilot.msu.edu
}

Article available at http://www.limnology-journal.org or http://dx.doi.org/10.1051/limn/2003004 


\section{Introduction}

Utilization of terrestrially derived nutrients (e.g., leaf litter) is considered to be critical to the productivity and spatial/temporal organization of stream communities (Kaushik \& Hynes 1971, Cummins 1974, Vannote et al. 1980, Cummins et al. 1989). Coastal streams that serve as spawning grounds for salmon (Oncorhynchus spp.) have an additional nutrient source termed marine-derived nutrients (MDN) in the form of salmonid eggs, sperm, metabolic waste, and adult carcasses. The role that these nutrients play in coastal systems has been the object of study in recent years. It has been suggested that salmon provide an essential nutrient source to the typically oligotrophic anadromous streams of the Pacific Northwest and, by subsidizing the nutrient base in their spawning grounds, increase the viability of their own offspring (Kline et al. 1997, Lichatowich 1999). Most studies have dealt with tracing MDN through various surface-stream and riparian trophic levels or quantitative comparisons of stream communities with and without salmon (e.g., Bilby et al. 1996, Kline et al. 1997, Ben-David et al. 1998, Wipfli et al. 1998, Cederholm et al. 1999, Chaloner et al. 2002). There is evidence of the incorporation of MDN into stream communities (Schuldt \& Hershey 1995, Bilby et al. 1996) and the short-term stimulation of primary production and increases in certain fauna (i.e., chironomid midges) (Kline et al. 1997, Wipfli et al. 1998, Wipfli et al. 1999, Chaloner et al. 2002). However, the long-term influence (i.e., through the winter and into the spring the following year) of MDN on the productivity of these streams is still unclear.

The importance of MDN to a stream community will depend on how far upstream the enrichment extends and the length of time these nutrients are retained in the system. Nutrient carry-over is particularly important for insects that acquire most of their biomass later in the year, months after salmon spawning. Insect responses to enrichment take several forms including changes in population size, voltinism, fecundity, and growth rates (e.g., Anderson \& Cummins 1979, Sweeney 1984, Arsuffi \& Suberkropp 1986, Peterson et al. 1993).

Several studies, as well as observations by the authors, have indicated that trichopterans are attracted to and feed on salmon and other fish carcasses (Brusven \& Scoggan 1969, Chaloner et al. 2002). Minakawa (1997) found greater growth in trichopterans directly feeding on MDN (i.e., salmon carcasses). The indirect influence of MDN on insect growth, however, is poor- ly understood. The objectives of this study were to : 1) address the question of long-term MDN subsidy via indirect pathways (i.e., nutrient carry-over) by comparing the spring growth of caddisflies above and below a natural barrier to salmon in an Alaskan stream ; and 2) compare the growth of selected caddisflies that are known to have different feeding modes (i.e., shredding and scraping) on leaves and biofilm. We hypothesized that if MDN does in fact provide an important longterm nutrient subsidy to these streams, then organisms grown below the waterfall barrier (i.e., with MDN in the system) would exhibit higher growth rates than organisms grown above the barrier (i.e., without MDN). The mechanism for increased growth was assumed to be greater food quality in the downstream section. We also hypothesized that when provided with either leaf litter or biofilm on rocks as food, shredders would grow better on leaves and scrapers would grow better on biofilm. The organisms selected have at least a oneyear life cycle and in some circumstances take two years before metamorphosis ; therefore, the influence of MDN would be integrated over the entire year. The timing of this study, however, was chosen to determine if MDN influences caddisfly growth in the spring, eight months after the autumn salmon run.

\section{Methods and materials}

\section{Study site}

Harris River is located on Prince of Wales Island, which is approximately 45 miles west of Ketchikan in Southeast Alaska. It receives annual spawning runs of coho (Oncorhynchus kisutch), pink (O. gorbuscha), and chum (O. keta) salmon. The largest spawning runs are the pink and chum spawning migrations, which normally take place between late July and early September. Harris River received an estimated 920,000 chum and pink salmon during autumn of 2000, prior to the experiment (Alaska Department of Fish \&Game, unpublished data). Harris River has a natural waterfall that blocks salmon migrations from "upstream" reaches. Unpublished data from the United States Geological Survey indicated that streams on Prince of Wales Island had average monthly discharges that were below average throughout the fall of 2000 and spring of 2001, but no discharge data was taken from the Harris River itself. Results of preliminary habitat sampling showed that reaches above and below the waterfall (termed upper and lower Harris) were of similar mean depth $(\sim 40 \mathrm{~cm})$, had similar bottom substrate (primarily small to large cobble and boulders) and riparian vegetation (mixtures of conifer and alder 
trees, shrubs, ferns, and herbaceous plants), but lower Harris was wider (average stream width was 29.4 versus $13.6 \mathrm{~m}$ ) and had less wood debris (average wood surface area was 0.03 versus $0.62 \mathrm{~m}^{2}$ wood $/ \mathrm{m}^{2}$ stream bottom) than upper reaches (Lessard, unpublished data).

\section{Study Organisms}

The limnephilid caddisflies we selected for study were Onocosmoecus unicolor (Banks), Dicosmoecus atripes (Hagen) and Psychoglypha spp., all of which are fairly common fauna in streams of Southeast Alas$\mathrm{ka}$. All three of these genera have also been associated with fish carcasses (Brusven \& Scoggan 1969, Chaloner et al. 2002). These species vary in their primary modes of feeding. Both O. unicolor and Psychoglypha spp. are considered obligate shredders (Wiggins \& Mackay 1978, Merritt \& Cummins 1996), whereas D. atripes larvae are facultative scrapers and shredders as early instars and shredders-predators during later instars (Wiggins \& Richardson 1982, Gotceitas \& Clifford 1983). All of these species were found in both stream sections of the Harris River. Preliminary, quali- tative sampling revealed, however, that downstream of the barrier there was a greater abundance of $O$. unicolor and $D$. atripes while upstream there were more Psychoglypha spp.

\section{Growth study}

The experiment began on 18 May 2001, at which time caddisflies were sampled from both upper and lower Harris River. Due to the distribution of all three taxa in the Harris River, all O. unicolor and D. atripes used in the experiment were from the lower reach and all Psychoglypha spp. used were from the upper reach. There were some size differences among the instars of $D$. atripes larvae : two general groups of $2^{\text {nd }}-3 \mathrm{rrd}^{\text {rd }}$ instars, and $3^{\text {rd }}-4^{\text {th }}$ instars. Each of these size class groups was grown separately and the number of individuals varied between 5 and 10 per growth box (Figure 1). O. unicolor and Psychoglypha spp. were grouped into one size class.

Insects were captured from cobble, side areas, and pools using D-frame nets. After sampling each reach, caddisflies were sorted and placed into growth boxes (modified $25 \times 18 \times 5 \mathrm{~cm}$ plastic containers with sec-

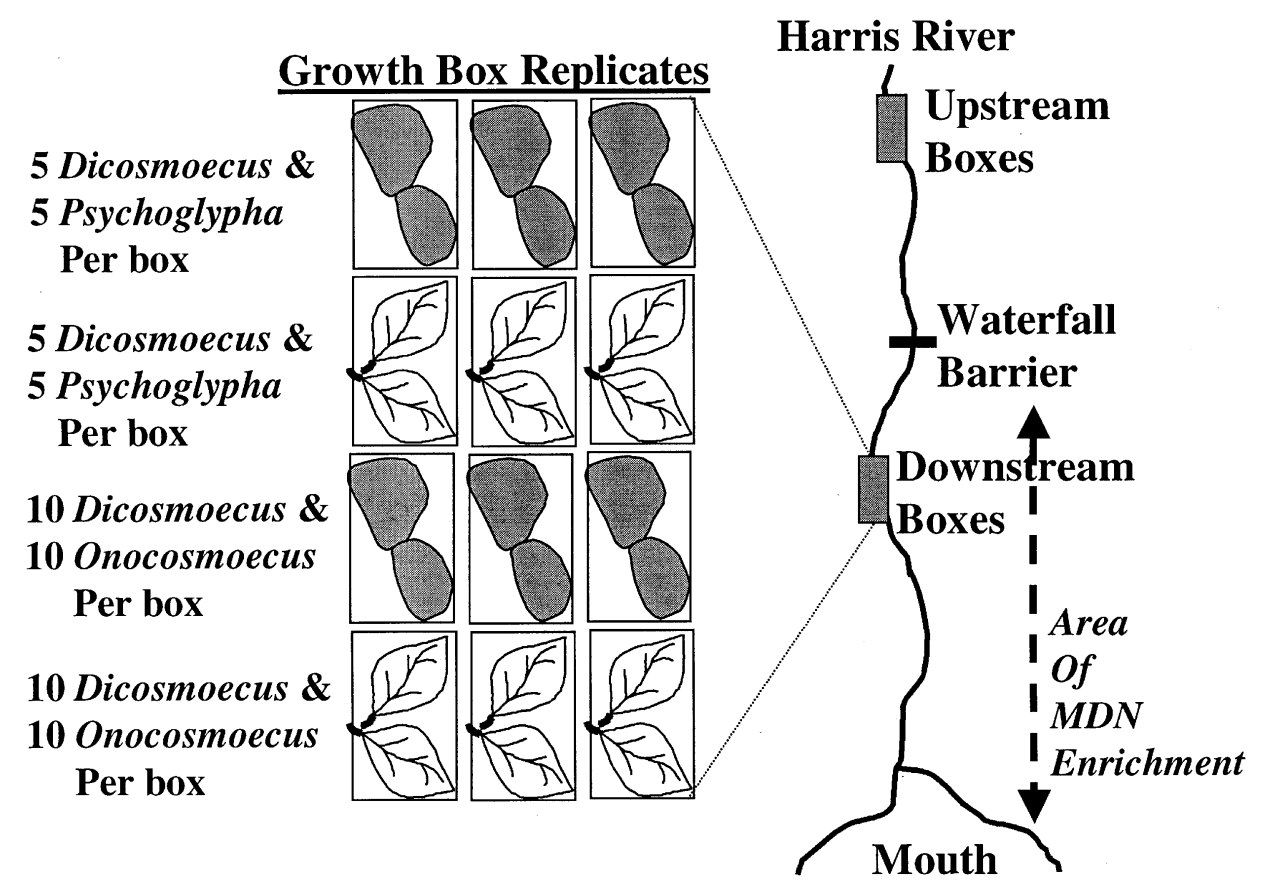

Figure 1. Schematic of growth experiment conducted in the Harris River. Identical set-ups were used in upstream and downstream sections. Box cartoons show the combinations of food type (conditioned alder leaves and rocks from the stream) and taxa that were put in each box, and replicated three times. 
tions of the top, sides and bottoms cut out and replaced with $2 \mathrm{~mm}$ plastic mesh). Food for the growth boxes consisted of either 12 conditioned (incubated in the stream for 2 weeks) red alder leaves (Alnus rubra Bong) or biofilm (defined as a matrix of algae, bacteria, fungi, protozoans and other organic matter) on 4-5 small rocks from the stream, both were inspected and had any insects removed before being put into the growth boxes. Caddisflies from each section $(D$. atripes and $O$. unicolor from downstream, Psychoglypha spp. from upstream) were grown in both sections (above and below the waterfall) and on both food types (conditioned leaves or biofilm on rocks). Each box contained D. atripes and either O. unicolor or Psychoglypha spp., so that one of the obligate shredders and the facultative scraper were in each box. Five $3^{\text {rd }}-4^{\text {th }}$ instar D. atripes and 5 Psychoglypha spp. were placed in each of 6 boxes ( 3 filled with leaves and 3 filled with rocks), while $10 \mathrm{O}$. unicolor and $102^{\text {nd }}-3^{\text {rd }}$ instar $D$. atripes were placed in another 6 boxes ( 3 filled with leaves and 3 filled with rocks). A total of 12 boxes were placed in each stream section (Figure 1) and were cable tied to rebar (metal rods $\sim 1.25 \mathrm{~cm}$ diameter) imbedded in the stream bottom in a slow flow area near the stream bank. Onset ${ }^{\circledR}$ temperature loggers were also placed in each stream section and set to record hourly readings. The remaining organisms from the stream samples of each caddisfly taxa (30-50 individuals per taxa) were used to obtain an initial population mean wet length and dry weight for each. These organisms were coaxed from their cases from the rear with a blunt probe, measured to the nearest $0.5 \mathrm{~mm}$, oven dried $\left(30^{\circ} \mathrm{C}\right.$ for four days) and weighed to the nearest $0.01 \mathrm{mg}$ using a Cahn-Electrobalance.

Boxes were monitored throughout the experiment to assess evidence of tampering or sedimentation. Rocks were changed twice and the leaves once and conifer needles also were added. This was done to provide case-making material and ensure access to food to minimize any growth box effect not representative of instream growth. On 26 June, after 40 days, the experiment was terminated. All insects were removed from the boxes, counted and kept separate for processing. At this time another large, in-stream sample (20-30 individuals) of each caddisfly taxa was taken from the Harris River to obtain a final in-stream population mean wet length and dry weight for each. All insects (from growth boxes and upstream and downstream instream samples) were brought back to the lab alive and processed the same way the initial samples were (i.e., coaxed from cases, measured for length, dried and weighed). Temperature loggers were also removed and data downloaded.
Instars were determined by measuring the width of the head, dorsally across the eyes, using an ocular micrometer at 70x to the nearest $0.05 \mathrm{~mm}$ (Wiggins \& Richardson 1982, Gotceitas \& Clifford 1983, Wiggins \& Richardson 1986). Mean length and dry weight for each caddisfly taxa was computed for insects grown in the boxes and for insects from the stream initially and at the end of the experiment. Insects lost from the boxes during the experiment were assumed dead, therefore percent survival of each taxa in each box was calculated from the number remaining divided by the number added initially times 100 . Mann-Whitney U tests, which utilize the $\chi^{2}$ distribution, were used for all pair-wise comparisons. Growth box effects were examined by comparing average final weights in the boxes in each section versus average final weights of free-living larvae from the stream. MDN effects were determined by comparisons of growth between stream sections (i.e., above versus below). Food preferences were determined by comparing growth on leaves versus biofilm on rocks. Descriptive statistics, regressions and Mann-Whitney U tests were all computed using Systat statistical software. Statistical significance was determined using $\alpha=0.05$ for independent comparisons. Bonferroni adjustments to alpha were made for multiple comparisons.

\section{Results}

Both D. atripes and Psychoglypha spp grew during the experiment and had similar final mean weights in the boxes as in the stream (i.e., there was no growth box effect) (Figure 2). O. unicolor were not growing in the stream during this experiment and were significantly smaller in the boxes than in the stream $\left(\chi_{\mathrm{df}=1}^{2}=13.349, \mathrm{p}<0.0001\right)$. No significant differences in growth between stream sections were detected for any of the caddisfly taxa. All three taxa, however, showed varied growth by food type with both $O$. unicolor and Psychoglypha spp. growing significantly more on leaves $\left(\chi_{\mathrm{df}=1}^{2}=10.829, \mathrm{p}=0.001\right.$; $\chi_{\mathrm{df}=1}^{2}=10.763, \mathrm{p}=0.001$, respectively) and $D$. atripes growing significantly more on biofilm on rocks $\left(\chi_{\mathrm{df}=1}^{2}=14.578, \mathrm{p}<0.0001\right)$ (Figure 2).

The upstream reach accumulated 282 degree-days $\left({ }^{\circ} \mathrm{C}\right)$ throughout the 40-day experiment, while downstream accumulated 215 degree-days $\left({ }^{\circ} \mathrm{C}\right)$. Normalizing for temperature, that is by comparing relative growth rates (RGR) per degree-day [calculated as : 100* (mean initial weight-mean final weight) /(mean initial weight $*$ \#of degree-days)] revealed similar results. O. unicolor and Psychoglypha spp. had significantly 


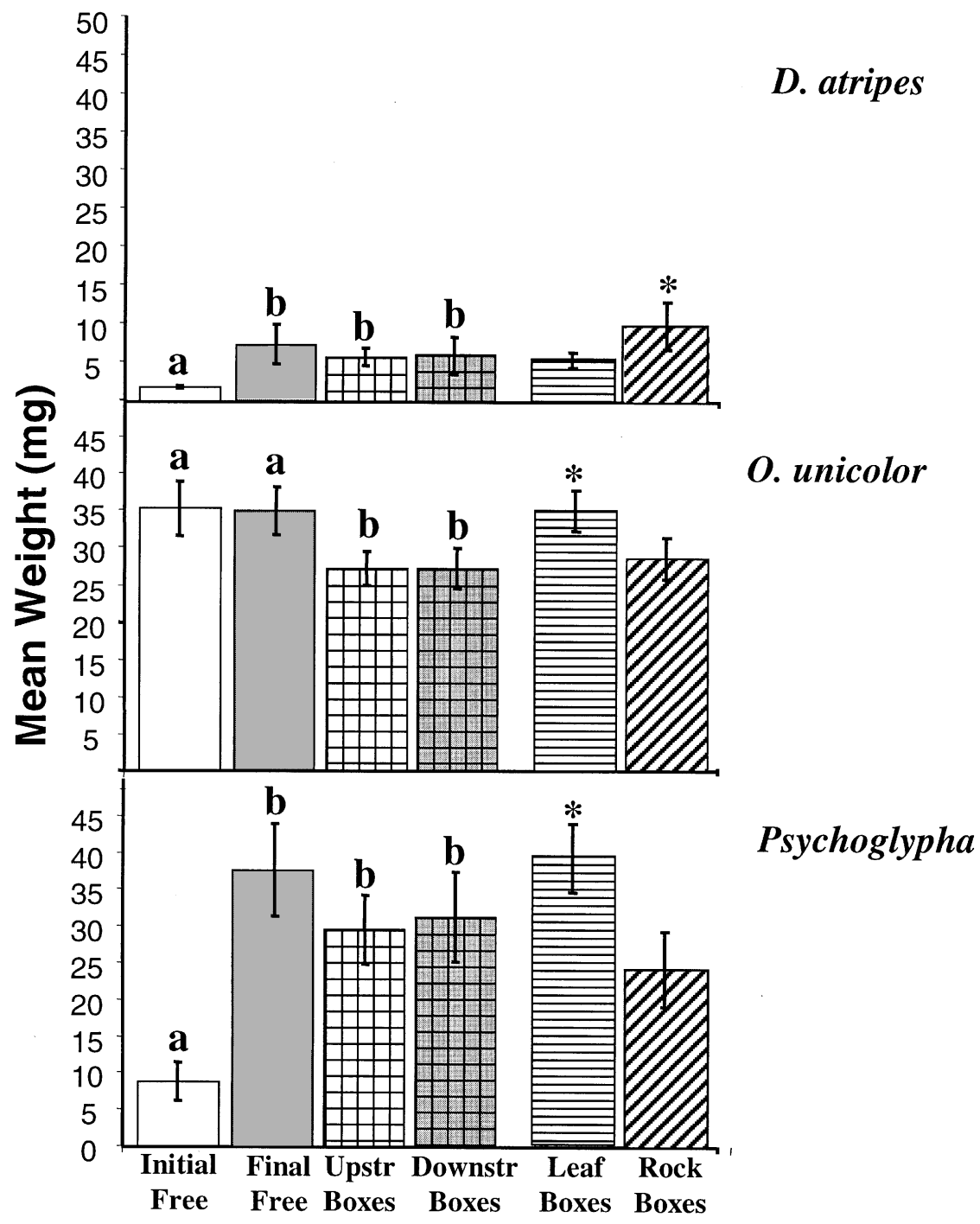

Figure 2. Mean dry weight mg (+/- SE) of caddisflies from the in-stream samples initially and at the end of the experiment, and from caddisflies confined to the boxes divided by stream section (ups$\operatorname{tr}=$ above the waterfall, downstr = below the waterfall) and food type (leaf and rock). MDN and growth box effects were determined by comparing free and boxed individuals by section (significant differences indicated by different letters) and food effects were determined by comparing food types (significantly higher values indicated by *). 


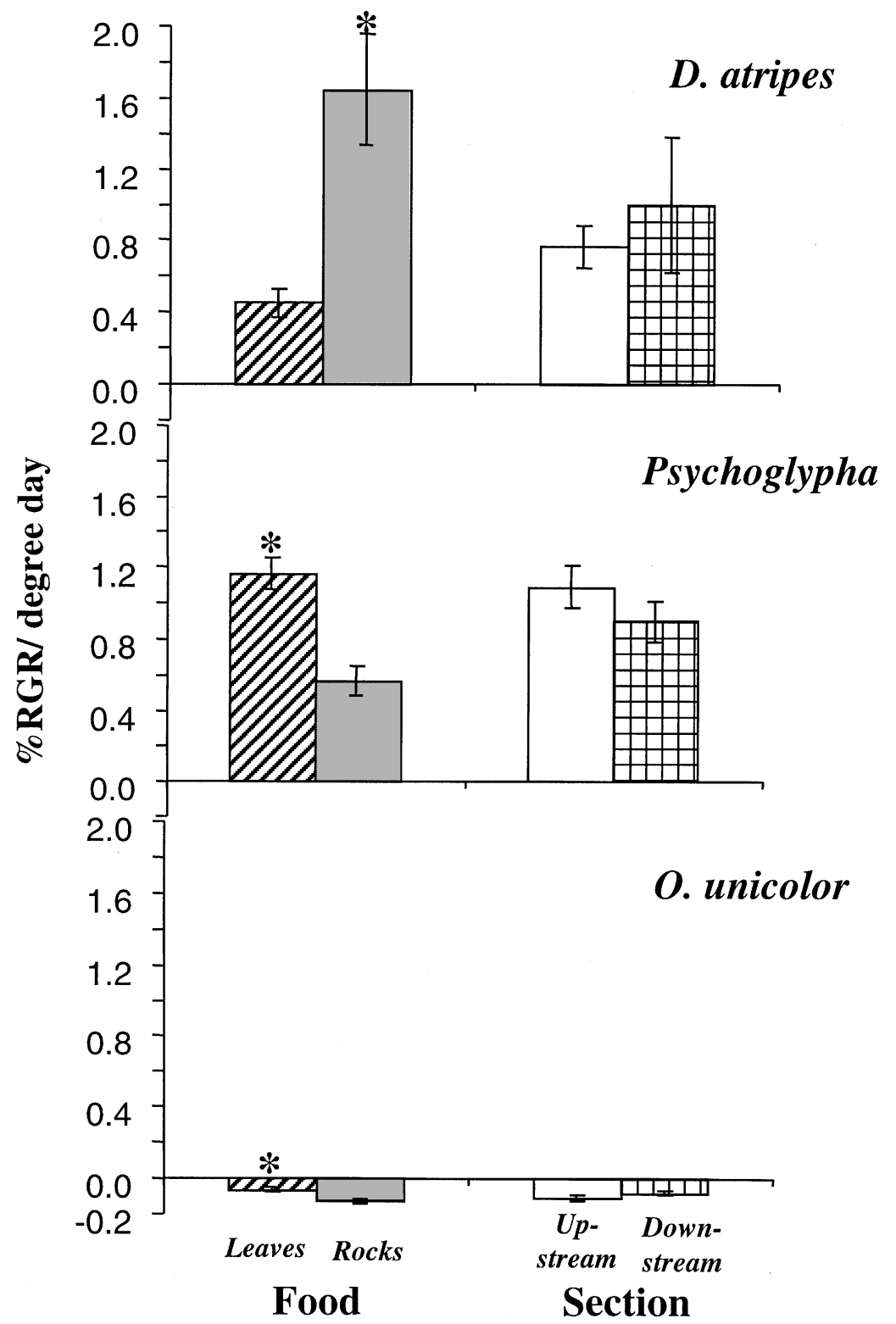

Figure 3. Mean \% relative growth rate (RGR)/ degree day $\left({ }^{\circ} \mathrm{C}\right)(+/-\mathrm{SE})$ for caddisflies grown in growth boxes averaged by food type and stream section. An * indicates significantly greater $\%$ RGR. 
greater growth rates on leaves $\left(\chi_{\mathrm{df}=1}^{2}=10.98\right.$, $\mathrm{p}=0.001 ; \chi_{\mathrm{df}=1}^{2}=10.345, \mathrm{p}=0.001$, respectively), and $D$. atripes had a significantly greater growth rate on biofilm $\left(\chi_{\mathrm{df}=1}^{2}=14.295, \mathrm{p}<0.0001\right)$ (Figure 3). There was no difference between above and below mean RGR for each caddisfly taxon.

Nearly all the boxes had some loss (assumed to be mortality) of caddisflies (Figure 4). A greater percentage of $D$. atripes compared to the other two taxa were lost during the experiment in both stream sections, but significantly more $D$. atripes survived in boxes from the downstream reach $\left(\chi_{\mathrm{df}=1}^{2}=4.669, \mathrm{p}=0.031\right)$. Psychoglypha spp. was the only taxon that showed a food effect on mortality, with a significantly greater percentage surviving on leaves $\left(\chi_{\mathrm{df}=1}^{2}=8.539, \mathrm{p}=\right.$ 0.003). Comparisons of mean $\%$ RGR/degree-day versus $\%$ mortality in the growth boxes, revealed significant negative models for $D$. atripes and Psychoglypha spp. but the high degree of variation made these relationships quite weak, especially for $D$. atripes (Adjusted $\mathrm{R}^{2}=0.19$ and $0.45, \mathrm{p}=0.022$ and 0.010 respectively) (Figure 5). There was no relationship between

Upstream Boxes

$\square$ Downstream Boxes

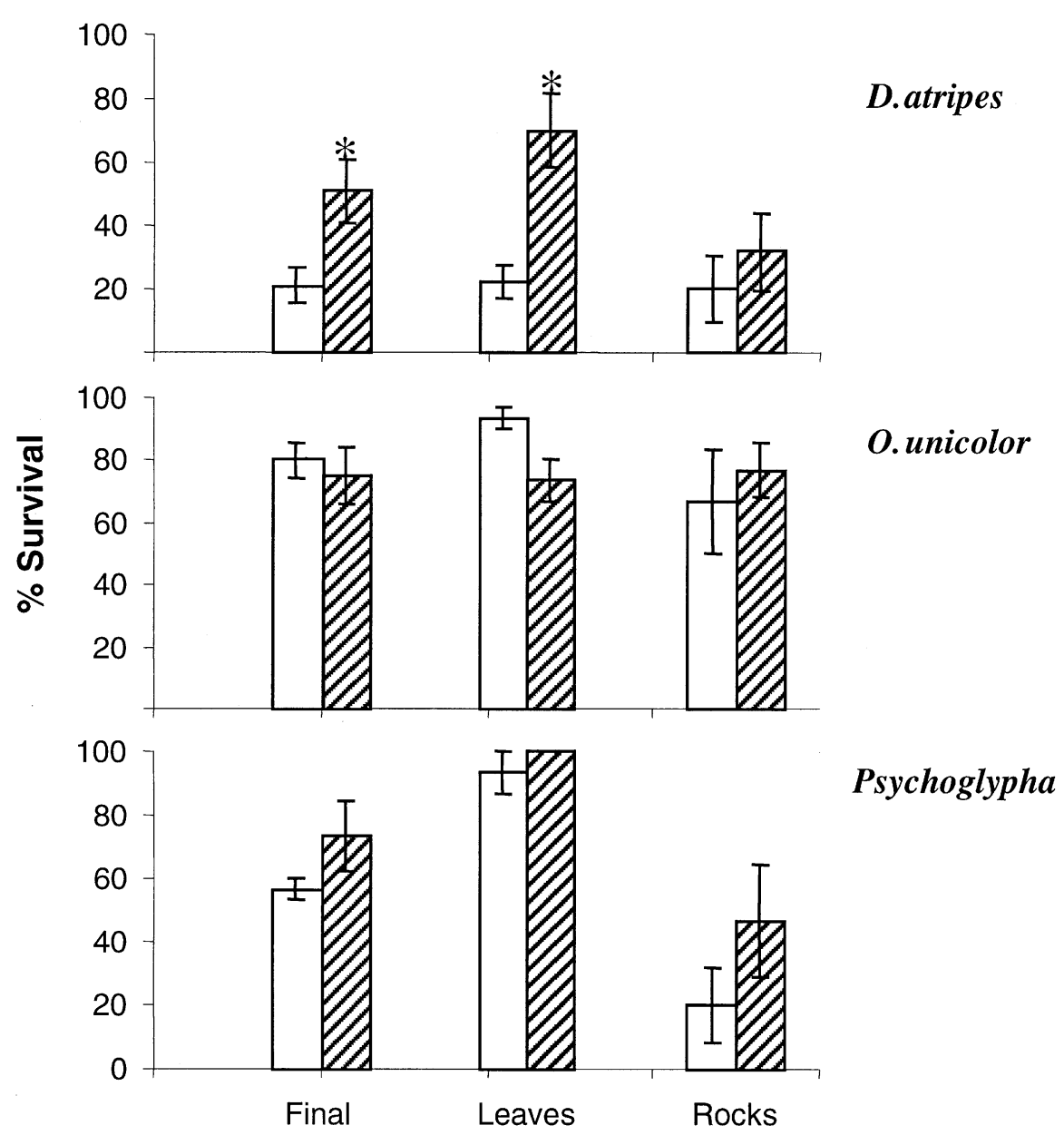

Figure 4. Mean percent survival (+/- SE) of caddisflies in the growth boxes at the end of the experiment divided by stream section (averaged across food type). Survival at the end of the experiment is also shown divided by food type in each section (Leaves and Rocks). Significant differences between stream sections (i.e., each pair of bars) are indicated by an*. 


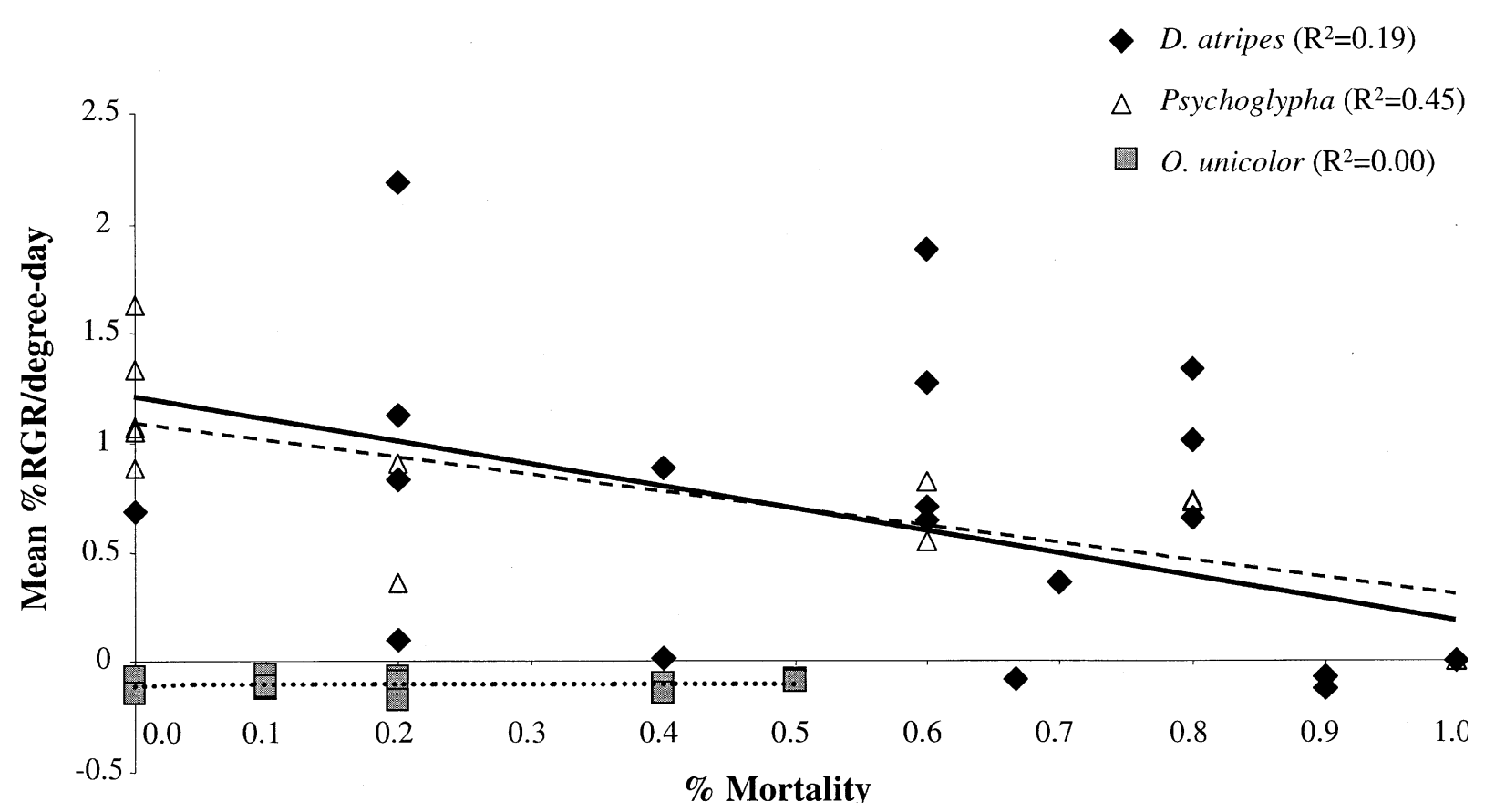

Figure 5 . Mean \% relative growth rate (RGR)/ degree day $\left({ }^{\circ} \mathrm{C}\right)$ versus \% Mortality in the growth boxes for each caddisfly. The lines are the results of the regressions $(D$. atripes $=$ solid line, Psychoglypha $=$ dashed line, $O$. unicolor $=$ dotted line $)$ and the symbols are from the data for each taxa. Adjusted $\mathrm{R}^{2}$ values for each model are given in the legend.

mean $\% \mathrm{RGR} /$ degree-day and $\%$ mortality for $O$. unicolor (Adjusted $\mathrm{R}^{2}=0.00, \mathrm{p}=0.895$ ) (Figure 5).

The large number of individuals and range of sizes of D. atripes and Psychoglypha spp. larvae analyzed during this experiment allowed us to develop strong wet length-dry weight relationships (Adjusted $\mathrm{R}^{2}=$ $0.95, \mathrm{p}<0.0001$ and $0.91, \mathrm{p}<0.0001$ respectively) (Figure 6). However, the small range in sizes for $O$. unicolor larvae (due to their lack of growth) made it difficult to establish a good length-weight equation for this species (Adjusted $\mathrm{R}^{2}=0.49, \mathrm{p}<0.0001$ ). Preliminary analysis revealed that the length-weight data were not linear so a natural log transformation was performed to produce a linear fit. The regression equations for these data were :

$$
\begin{aligned}
& \text { D. atripes }(\mathrm{n}=221) \operatorname{Ln}(\mathrm{w})=0.421 \mathrm{~L}-1.865 \\
& \text { Psychoglypha }(\mathrm{n}=62) \operatorname{Ln}(\mathrm{w})=0.331 \mathrm{~L}+0.04 \\
& \text { O. unicolor }(\mathrm{n}=126) \operatorname{Ln}(\mathrm{w})=0.269 \mathrm{~L}+1.716
\end{aligned}
$$

Where $\operatorname{Ln}(\mathrm{w})$, is the natural log of the dry weight $(\mathrm{mg})$ and $\mathrm{L}$ is the total wet length $(\mathrm{mm})$.

\section{Discussion}

There was no detectable influence of MDN on the spring growth of these three limnephilid caddisflies in Harris River. O. unicolor hatch in the fall and grow quickly to fifth instars and then remain at that stage over the winter and spring, pupating and emerging during summer (Wiggins \& Richardson 1986, Irons 1988). Head capsule width measurements revealed that the Harris Riverís population of $O$. unicolor larvae were fifth instars throughout our experiment. The limited abundance of $O$. unicolor above the waterfall during our experiment prevented meaningful in-stream above and below comparisons of weights. However, the abundance of this species in areas that receive salmon nutrients might be related to MDN. The life cycle of this species is timed to obtain the greatest advantage from the salmon, with most larval growth occurring in autumn during salmon carcass decomposition (Irons 1988). Onocosmoecus sp. are commonly found associated with salmon carcasses after spawning runs in streams in the Pacific Northwest (Minakawa 1997, Chaloner et al. 2002). However, spawning also coin- 
cides with the primary time for deciduous leaf fall so this shredder's life history may be keyed to the salmon, leaf litter inputs, or both.

$D$. atripes also were found in greater numbers downstream. $D$. atripes was the only taxon that showed mortality variation between stream sections, with significantly more surviving in the downstream boxes. It is possible that niche partitioning in this stream relegates $D$. atripes and $O$. unicolor to downstream reaches and Psychoglypha spp. to upstream areas, with further separation temporally of $D$. atripes and $O$. unicolor larval growth periods. The growth boxes did not support this hypothesis, however, because more $D$. atripes were lost in boxes with $O$. unicolor, their natural physical companion, but these boxes also had twice as many and younger $D$. atripes individuals in the boxes. Lamberti et al. (1995) found evidence for density dependent growth of the scraping $D$. gilvepes in laboratory streams. In our experiment there was a weak negative relationship between $\%$ mortality and

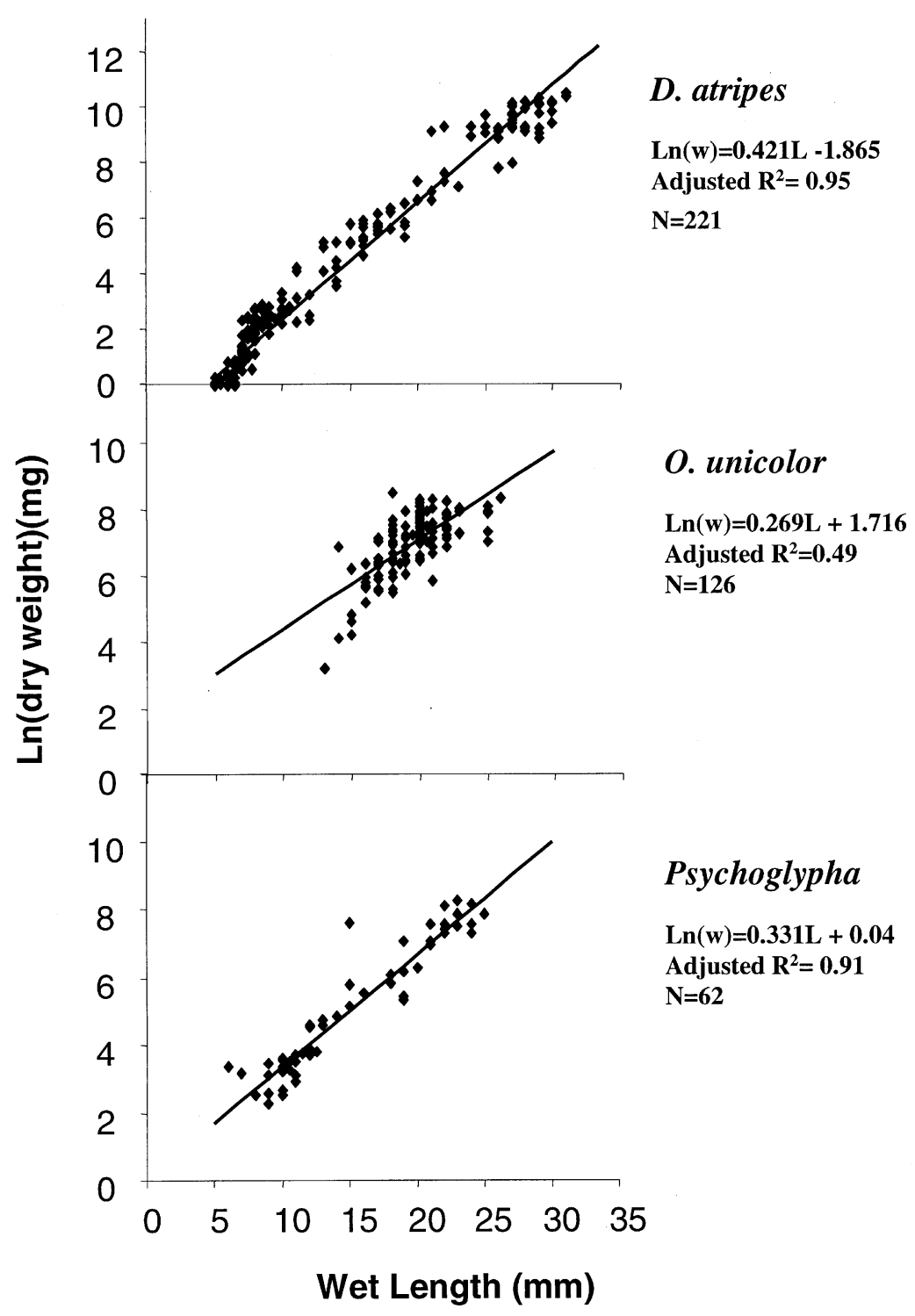

Figure 6. Wet length-dry weight relationships for the three caddisflies. Lines are the results of regression equations shown to the right of each graph and diamonds are the individual data points from in-stream samples of each taxon. 
$\%$ growth for $D$. atripes, so it appeared that boxes that lost more individuals were somehow also systematically poorer environments for growth. Due to the complexity of this experiment, however, and the number of potentially interacting factors, we were not able to determine inter- or intra-specific competitive interactions in the stream or in our growth boxes.

The main growth period for $D$. atripes is during the spring and early summer (Wiggins \& Richardson 1982, Gotceitas \& Clifford 1983). Although they grew during our experiment, we were not able to detect an influence of MDN on the spring growth of this species either. This species is most likely a scraper, at least as earlier instars because $D$. atripes grew less when supplied conditioned leaves than when supplied biofilm in the boxes. Other feeding and growth studies on late and middle instar $D$. atripes larvae concluded that this species is a shredder and sometimes a predator (Wiggins \& Richardson 1982, Mihuc \& Mihuc 1995). Our data support those of Gotceitas \& Clifford (1983) in Alberta, Canada who found that $D$. atripes utilize algae as their main food source in the first year of their life cycle.

During the second sampling period we found several very large $D$. atripes larvae that had switched their case making from organic to mineral. Head-width analysis revealed that during our original sampling we had primarily $2^{\text {nd }}$ and $3^{\text {rd }}$ instars and during the second sampling we had $3^{\text {rd }}, 4^{\text {th }}$, and $5^{\text {th }}$ instars (Wiggins \& Richardson 1982). D. atripes larvae have been shown to have two-year life cycles in cold streams (Gotceitas \& Clifford 1983). D. atripes in the Harris River also appeared to have a two year life-cycle, which accounted for $5^{\text {th }}$ instars being found during the second sampling. Second year $D$. atripes larvae over-winter as diapausing fifth instars attached in large aggregations under large boulders, and then become active again in the spring (Gotceitas \& Clifford 1983). Dicosmoecus larvae were shown to be important processors of fish carcasses in a study of northern pikeminnow (Ptychocheilus oregonensis) eradication in Idaho (Brusven \& Scoggan 1969). Since D. atripes larvae remain in this stream throughout the spawning run and carcass decomposition, before the winter diapause, the importance of MDN to this species may occur during that time (i.e., between its first and second year of development) rather than at the beginning of the life-cycle.

Psychoglypha spp. are shredding caddisflies limited to the western montane regions of North America (Denning 1970, Wiggins \& Mackay 1978, Merritt \& Cummins 1996). Not much is known of the life history of this genus except that they are cold adapted and adults have been found between late fall and early spring in Southeast Alaska and from April to August in the Yukon (Ellis 1978, Wiggins \& Parker 1997). Growth studies of Psychoglypha spp. found that these caddisflies grew differently on varying food quality and exhibited high relative growth rates $(0.51 \%$ body weight/degree day) on the highest quality food (Arsuffi \& Suberkropp 1986). Psychoglypha spp. in our study grew on average at a similar rate on the biofilm and at over twice that rate on the stream-conditioned alder leaves, indicating the generally high growth achieved by this taxon in the Harris River. These high growth rates were similar between stream sections and slightly higher in upstream sections, which again points to the lack of importance of MDN to the spring growth of this caddisfly. Psychoglypha spp. have been observed numerous times on fish carcasses (Brusven \& Scoggan 1969, Piorkowski 1995, Minakawa 1997, Chaloner et al. 2002), indicating the potential for a direct relationship between MDN and this caddisfly. When Psychoglypha subborealis larvae were grown in cages with either salmon carcass chunks and leaves or leaves alone, $P$. subborealis showed higher growth rates in the presence of the salmon tissue (Chaloner \& Wipfli 2002). The dominance of Psychoglypha spp. above the barrier, however, and their high growth rates upstream and probable emergence prior to salmon decomposition in the Harris River indicates less of a reliance on these nutrients in this system.

\section{Conclusions}

Salmon impact stream communities that receive them, from the huge disturbance caused by their numbers and spawning activity to the pulse of nutrients released following this activity and ultimately to the stream fish community by the addition of their offspring (Kline et al. 1997, Minakawa, 1997, Wipfli et al. 1998, Peterson \& Foote 2000). Initial post-spawning increases of dissolved nutrients and biofilm, however, are mainly due to the incorporation of salmon metabolic waste, sperm, and eggs into stream communities, all of which are temporary forms of MDN. The question is, how is the stream community affected through the rest of the year? Is this MDN enrichment retained in the system long enough to affect fauna that are not active in the stream during the initial autumn MDN pulse ?

After spawning has ended and salmon begin dying off, the retention of these blocks of MDN (i.e., carcasses) becomes a function of hydrologic retention and stream structure (e.g., wood debris, surface topogra- 
phy), as are all sources of coarse particulate organic matter (Speaker et al. 1984, Cederholm \& Peterson 1985). Retention would have to involve sequestration of nutrients in the surface and subsurface and the slow release and cycling of these nutrients throughout the year. The simplest slow release mechanism to visualize would be from the burial and subsequent aerobic and/or anaerobic decomposition of whole carcasses and pieces, an area yet to be researched. A more complicated mechanism would be from the stimulation of production of autumnal flora and fauna that would cycle these nutrients via the surface and hyporheic food web at a magnitude and rate that allows for an influence on other organisms months later. To our knowledge no research has been able to trace nutrients through a stream system for that long.

By comparing growth of these caddisflies on both biofilm on rocks and fungi on leaves we were able to look indirectly at variations in food quality between stream sections as well as establishing which food type each taxa preferred. This study revealed strong food preferences by all three caddisflies, which followed what was hypothesized. This study also suggests that MDN enrichment in Harris River may not have extended into subsequent generations of caddisflies and, therefore, growth of larvae in the spring was not different between areas with and without salmon. Further research should continue and include abundance and production estimates of these caddisflies as well as studies on insect growth and life history in the fall and winter to help clarify the role of MDN more proximal to the salmon migration. The MDN effects appear to be much more complicated than the simple models that link salmon enrichment, stream productivity, and ultimately a positive feedback for juvenile salmon survival via direct and indirect pathways. The complications come from the coincidental substrate disturbance of spawning that precedes MDN enrichment, varied life histories of aquatic insects, and the lack of knowledge of the fate of MDN in streams over longer periods of time. Links to fish production may take place over the few weeks or months directly following the major salmon run and therefore the influence on the stream community as a whole may be more limited than many hypotheses predict.

\section{Acknowledgements}

This manuscript was improved greatly from the reviews and advice of R. Wotton, J. Richardson, J. Wallace, and G. Lamberti. C. Lesage and R. Kimbirouskas were invaluable with setting up this experiment. Thanks to M. Wipfli for support and the USFS Pacific Northwest Research Station for the use of their housing and research facilities in Hollis, Prince of Wales Island, AK. This research was supported by the following : USDA National Needs Water Science Fellowship Program, USDA-CRSEES National Research Initiative Competitive Grants Program (Ecosystem Science Program) and Sigma Xi Grants in Aide of Research.

\section{References}

Anderson N.H. \& Cummins K.W. 1979. - The influence of diet on the life histories of aquatic insects. J. Fish. Res. Bd. Can., 36 : 342-355.

Arsuffi T.L. \& Suberkropp K. 1986. - Growth of two stream caddisflies (Trichoptera) on leaves colonized by different fungal species. J. N. Am. Benthol. Soc., 5 : 297-305.

Ben-David M., Hanley T.A. \& Schell D.M. 1998. — Fertilization of terrestrial vegetation by spawning Pacific salmon : the role of flooding and predator activity. Oikos, $83: 47-55$.

Bilby R.E., Fransen B.R. \& Bisson P.A. 1996. - Incorporation of nitrogen and carbon from spawning coho salmon into the trophic system of small streams : evidence from stable isotopes. Can. J. Fish. Aquat. Sci., 53 : 164-173.

Brusven M.A. \& Scoggan A.C. 1969. - Sarcophagous habits of Trichoptera larvae on dead fish. Ent. News, 80 : 103-105.

Cederholm C.J. \& Peterson N.P. 1985. — The retention of coho salmon (Oncorhynchus kisutch) carcasses by organic debris in small streams. Can. J. Fish. Aquat. Sci., 42 : 1222-1225.

Cederholm C.J., Kunze M.D., Murota T.M. \& Sibatani A. 1999. Essential contributions of nutrients and energy for aquatic and terrestrial ecosystems. Fisheries, $24: 6-15$.

Chaloner D.T. \& Wipfli M.S. 2002. — Influence of decomposing Pacific salmon carcasses on macroinvertebrate growth and standing stock in Southeastern Alaska streams. J. N. Am. Benthol. Soc., 21 : 430-442.

Chaloner D.T., Wipfli M.S. \& Caouette J.P. 2002. — Mass loss and macroinvertebrate colonization of Pacific salmon carcasses in south-eastern Alaskan streams. Freshwat. Biol., 47 : 263-273.

Cummins K.W. 1974. - Structure and function of stream ecosystems. Bioscience, $24: 631-640$.

Cummins K.W., Wilzbach M.A., Gates D.M., Perry J.B. \& Taliferro W.B. 1989. - Shredders and riparian vegetation. Bioscience 39 : 24-30.

Denning D.G. 1970. - The genus Psychoglypha (Trichoptera : Limnephilidae). Can. Ent., $102: 15-30$.

Ellis R.J. 1978. - Seasonal abundance and distribution of adult caddisflies of Sashin creek, Baranof Island, Southeastern Alaska. The Pan-Pac. Ent., 54 : 199-206.

Gotceitas V. \& Clifford H.F. 1983. - The life history of Dicosmoecus atripes (Hagen) (Limnephilidae : Trichoptera) in a rocky mountain stream of Alberta, Canada. Can. J. Zool., 61 : 586-596.

Grubbs S.A. \& Cummins K.W. 1994. — Processing and macroinvertebrate colonization of black cherry (Prunus serotina) leaves in two streams differing in summer biota, thermal regime and riparian vegetation. Am. Midl. Nat., 132 : 284-293.

Irons J.G., III. 1988. - Life history patterns and trophic ecology of Trichoptera in two Alaskan (U.S.A.) subarctic streams. Can. J. Zool., 66 : 1258-1265.

Kaushik N.K. \& Hynes H.B.N. 1971. - The fate of dead leaves that fall into streams. Arch. Hydrobiol., 68 : 465-515.

Kline T.C., Goering J.J. \& Piorkowski R.J. 1997. — The effect of salmon carcasses on Alaskan freshwaters. Pages 179-204 in Freshwaters of Alaska, ecological syntheses. Milner A.M. \& Oswood M.W. (Eds.). Springer-Verlag, New York.

Lamberti G.A., Gregory S.V., Ashkenas L.R., Li J.L., Steinman A.D. \& McIntire C.D. 1995. - Influence of grazer type and abundance on plant-herbivore interactions in streams. Hydrobiologia, 306 : 179-188. 
Lichatowich J.A. 1999. - Salmon without rivers, Island Press, Washington D.C. 317 p.

Merritt R.W. \& Cummins K.W. 1996. - An introduction to the aquatic insects of North America, Kendall/Hunt Publishing Co. $862 \mathrm{p}$.

Minakawa N. 1997. - The dynamics of aquatic insect communities associated with salmon spawning. Unpublished Ph.D. dissertation. University of Washington, Seattle.

Mihuc T.B. \& Mihuc J.R. 1995. - Trophic ecology of five shredders in a rocky mountain tream. J. Fresh. Ecol., 10 : 209-216.

Peterson B.J., Deegan L., Helfrich J., Hobbie J.E., Hullar M., Moller B., Ford T.E., Hershey A., Hiltner A., Kipphut G., Lock M.A., Fiebig D.M., McKinley V., Miller M.C., Vestal J.R., Ventullo R. \& Volk G. 1993. - Biological responses of a tundra river to fertilization. Ecology, 74 : 653-672.

Peterson D.P. \& Foote C.J. 2000. — Disturbance of small-stream habitat by spawning sockeye salmon in Alaska. Trans. Am. Fish. Soc., 129 : 924-934.

Piorkowski R.J. 1995. - Ecological effects of spawning salmon on several southcentral Alaskan streams. Unpublished Ph.D. dissertation. University of Alaska, Fairbanks.

Schuldt J.A. \& Hershey A.E. 1995. — Effect of salmon carcass decomposition on Lake Superior tributary streams. J. N. Am. Benthol. Soc., 14 : 2569-268.

Speaker R., Moore K. \& Gregory S. 1984. - Analysis of the process of retention of organic matter in stream ecosystems. Verh. Internat. Verein. Limnol., 22 : 1835-1841.
Sweeney B.W. 1984. - Factors influencing life-history patterns of aquatic insects. Pages 56-100 in The ecology of aquatic insects. Resh V.H. \& Rosenberg D.M. (Eds.). Praeger Publishers, New York, NY.

Vannote R.L., Minshall G.W., Cummins K.W., Sedell J.R. \& Cushing C.E. 1980. - The river continuum concept. Can. J. Fish. Aquat. Sci., 37 : 130-137.

Wiggins G.B. \& Mackay R.J. 1978. - Some relationships between systematics and trophic ecology in nearctic aquatic insects, with special reference to Trichoptera. Ecology, 59: 1211-1220.

Wiggins G. B. \& Parker C.R. 1997. — Caddisflies (Trichoptera) of the Yukon, with analysis of the Beringian and Holarctic species of North America. Pages 787-866 in Insects of the Yukon. Danks H.V. \& Downes J.A. (Eds.). Biological survey of Canada (Terrestrial Arthropods), Ottowa,.

Wiggins G.B. \& Richardson J.S. 1982. — Revision and synopsis of the caddisfly genus Dicosmoecus (Trichoptera : Limnephilidae; Dicosmoecinae). Aquat. Insects, 4 : 181-217.

Wiggins G.B. \& Richardson J.S. 1986. — Revision of the Onocosmoecus unicolor group (Trichoptera : Limnephilidae, Dicosmoecinae). Psyche, 93 : 187-216.

Wipfli M.S., Hudson J. \& Caouette J. 1998. — Influence of salmon carcasses on stream productivity : response of biofilm and benthic macroinvertebrates in Southeastern Alaska, U.S.A. Can. J. Fish. Aquat. Sci., $55:$ 1503-1511.

Wipfli M.S., Hudson J.P., Chaloner D.T \& Caouette J.P. 1999. — Influence of salmon spawner densities on stream productivity in Southeast Alaska. Can. J. Fish. Aquat. Sci., 56 : 1600-1611. 